Živković Danijel $^{1}$

Božić Miljković Ivana²

Mihić Svetlana ${ }^{3}$

Educons University, Faculty of Business Economy, Novi Sad
SCIENTIFIC REVIEW ARTICLE

DOI:10.5937/ekonomika1703043Z

Received May, 12, 2017

Accepted: May, 26, 2017

\title{
KNOWLEDGE OF FRENCH LANGUAGE AND CULTURE - A PRECONDITION FOR IMPROVING ECONOMIC RELATIONS BETWEEN SERBIA AND FRANCE
}

\begin{abstract}
France is one of the largest economies of the world and one of the most influential countries of the EU, and its centuries-old friendship with Serbia and a strategic position in the Western Balkans and the complementarity of economies represent a good basis for the development of bilateral economic relations. However, despite the great potential for cooperation, mutual cooperation results to date are not at a high level. One of the reasons may well be just the language barrier and the lack of knowledge of French market culture. The aim of this paper is to present forms of economic cooperation between Serbia and France, to emphasize the importance of the knowledge of French language and intercultural competence as a prerequisite for cooperation, at least in the initial marketing terms. In this paper, we will give a brief historical overview of the French economic relations, and by employing a complementary analysis we will present the mutual trade between the two countries, and we will as well point out the importance of knowing the French language and French culture to the employees who have plans for successful cooperation with French partners.
\end{abstract}

Key words: Serbia, France, intercultural relations, economic relations, business communication

JEL classification: F55, F40, F63, Z130

\section{ПОЗНАВАЊЕ ФРАНЦУСКОГ ЈЕЗИКА И КУЛТУРЕ - ПРЕДУСЛОВ ЗА ПОБОЉШАЫЕ ЕКОНОМСКИХ ОДНОСА СРБИЈЕ И ФРАНЦУСКЕ}

\begin{abstract}
Апстракт
Франиуска је једна од највећих економија света и једна од најутицајнијих земаља ЕУ, а вековно пријатељство са Србијом, њена стратешка позиција на Западном Балкану и комплементарност економија представљају добру основу за развијање билатералних економских односа. Ипак, поред великог потенцијала за сарадюу, резултати досадашње међусобне сарадње нису баш на завидном нивоу.
\end{abstract}

\footnotetext{
1 danijel.zivkovic@yahoo.com

2 ibozicmiljkovic@gmail.com

${ }^{3}$ svetlanamihic@gmail.com
} 
Један од разлога, између осталог, може да буде језичка баријера и непознавање културе франиуског тржишта. Циь овог рада је да прикаже облике економске сарадње између Србије и Франиуске и да укаже на значај познавања франиуског језика и интеркултурне компетениије, као један од предуслова за успостављање сарадње, макар у том почетном маркетиником погледу. Уовом раду ћемо најпре дати кратак историјски приказ франиуско-економских односа, компаративном анализом представићемо међусобну трговину између две земье и указаћемо на значај познавања франиуског језика и франиуске културе запослених који имају у плану успешну сарадюу са франиуским партнерима.

Кључне речи: Србија, Франиуска, интеркултурни односи, економски односи, пословна комуникаиија

\section{Introduction}

Today, France is one of the most influential countries of the European Union and one of the largest economies of the world, with a very large market of nearly 67 million people which provides huge business opportunities. The country has maintained traditionally good and friendly relations with Serbia for two centuries. If we take into account that Serbia is the main partner of France in the Western Balkans, it can certainly serve as the basis for improving economic relations between the two countries. However, businessmen in Serbia are often unaware of how the knowledge of French language is important for their development on the francophone market. While English language is sufficient for conducting business in most European countries, the situation is different in France. France is a country that clings to its cultural values, and is particularly strict in preserving its language, which is why the knowledge of French language and French culture is very important prerequisite for improving economic relations. For this reason, the aim of this work is to explain its purpose into a couple of steps. Firstly, the aim is to investigate and present forms of economic cooperation between Serbia and France. Secondly, it is to point out the ways for overcoming language barriers and to show not only cultural similarities, but also differences between the two countries, especially in economics, as well as in many other areas.

The paper will first present a brief historical overview of the Franco-Serbian relations that present the basis for further development of their bilateral relations in the contemporary European and global environment. Although during the nineties these bilateral relations had their ups and downs. The revitalization and improvement thereof have been noted over the last few years. This was contributed by the pro-European orientation of Serbia and its powerful aspirations towards joining the European Union. Since the beginning of the 21 st century up to date, France has become one of the most important foreign trade partners of Serbia, whereas its volume of investments in the Serbian economy has positioned itself among the top European investors. After analyzing mutual trade and presentation of the most important companies that have entered the Serbian capital market, we will present the sectors in which Serbia has the highest export potential when it comes to theFrench market. Preservation and promotion of future 
economic cooperation between Serbia and France necessarily imply the knowledge of the French language and French culture basics. Thus, a part of this paper will provide a brief overview of intercultural relations.

\section{History of the French-Serbian economic relations}

France became aware of its economic and geostrategic interests in Serbia during the 19th century. The first consulate of France in Serbia was founded in 1839. French consuls have realized the importance of The Principality of Serbia in regional trade so that, at the beginning of 1840, they established their first French-Serbian trade relations, whereby Belgrade became the crossroads of three roads towards Mediterranean ports. In that period, Serbian students began to study in Paris, and later on they formed the intellectual elite of Serbia. Formal diplomatic relations between Serbia and France were established on 1 January 1879. After the Berlin Congress, France's interests in economic affairs intensified even more. On the one hand, France, together with Germany and Austria-Hungary, participated in loaning funds, while its railway company participated in the construction of the railway network in Serbia on the other hand.

After the conclusion of the Franco-Russian alliance in 1893, French politicians and diplomats introduced the Balkans into their strategic considerations, and Serbia became a subject of growing interest in economic and cultural terms. Significant changes in foreign trade occurred in 1906, as well as after Serbia became open for new markets. Serbia soon became a point of interest for many French intellectuals and publicists. In 1910 the FrancoSerbian Bank was established, which contributed to the improving of the economic relations between the two countries to an even greater extent. After Peter 1st Karadjordjevic and Foreign Minister Milovan Milovanovic visited France, the bilateral relations continued to strengthen, so that in 1914 France achieved a dominant economic and cultural influence in Serbia. In historiography, much information was documented about the Franco-Serbian friendship during the First World War. Bilateral relations between the two countries reached its peak between the end of the war in 1918 and the assassination of King Alexander in Marseilles in 1934. However, in the period after the Second World War, influenced by new and changing international situation, the relations between France and Yugoslavia began to weaken. During the Algerian war and Yugoslavia's supporting of the Algerian independence, as well as during the bombing of Serbia in 1999 and France's recognition of Kosovo's independence, the bilateral relations between the two countries were at the lowest level (Sretenović, 2009; see Kovačević, 2012, pp. 45, 57, 324).

In recent years, the situation has significantly improved and the traditionally good relations were re-established, which has been manifested by the development of economic relations. Primarily, the Franco-Serbian-Montenegrin Business Club was established on 19 May 2005, while on 8 October 2009 it was transformed into the French-Serbian Chamber of Commerce. The goal of the chamber is to expand cooperation between the two countries, organization of public and business meetings. On Serbia's road towards the EU, several of the bilateral agreements ${ }^{1}$ have been signed, which have greatly facilitated business operations between the two countries. Thierry Repentin, delegated Minister of France for European Affairs, said in an interview for Politika that the Franco-Serbian bilateral relations had reached the former strength that they had after the signing of the Agreement on strategic 
partnership and cooperation (ASPC) between France and Serbia, as well as after the First World War (Politika, 2 September 2013). This agreement, which the two governments signed in April 2011, regulated the cooperation in the field of economy, energy, education, science, language, and culture. It is particularly important in the economy, because the French companies adhere to the recommendations of their governments in relation to markets and the countries recommended for investments.

\section{The mutual trade}

Two centuries of good Franco-Serbian relations constitute a solid basis for the development of bilateral cooperation in various fields, especially in economy. Serbia is the center of the Western Balkans, enabling it to have a strategic position. This fact is certainly of interest to the French investors who consider Serbia to be a strategic partner and who invested about 500 million euros of direct investments in the period from 2000 to 2013 alone. If we take into consideration the individual investment of French companies, investments reach 850 million euros ${ }^{2}$. French investors are present in different sectors:

- Banking and Insurance: Societe Generale, Crédit Agricole, Findomestic Bank as a member of the BNP Paribas and AXA Insurance;

- Automotive industry: Michelin (world leader in the production of tires and the third largest exporter of Serbia), Lohr (transport trailers), Streit jucit (auto supplier that has invested about 6 million euros in Serbia);

- Agrocultural industry: Bongrain (bought most of the production lines of Imlek), Lactalis, MEH (bought Sladara Maltineks);

- Information technology: Schneider electiric and Atos

- Foundry: Le Bélier (European leader in the production of aluminum components for the automotive industry).

Today in Serbia, around one hundred French companies employ about 11000 workers. Many companies, such as Lafarge, Michelin and Tarkett, reinvest in new business development and industrial production. These companies have invested 55\% of their investments in the production. One of the most important investments was the takeover of the cement factory Lafrage. With the help of joint ventures and the Michelin Tigar, in 1998, operations in the free zone Pirot started and has since achieved excellent results (Konstadinović \& Petrović-Randjelović, 2015, p. 102). France is still mostly interested in the sectors of energy and environmental protection, primarily for the construction of landfills, water treatment and triage centers (Marcon, 2016, p. 10). In addition, French government continues the discussion with Serbian authorities on joint infrastructure projects, notably the construction of the Belgrade metro, an investment worth around one billion euros, which the French Alstom is quite interested in. 
Table 1: Macroeconomic indicators of economic growth of Serbia and France in 2016

\begin{tabular}{|c|c|c|}
\hline & Serbia & France \\
\hline Area & $88.361 \mathrm{~km}^{2}(117 \mathrm{th})$ & $640.679 \mathrm{~km}^{2}(43 \mathrm{th})$ \\
\hline Population & 7. $143.921(103$ th $)$ & $66.836 .154(22$ th $)$ \\
\hline GDP (PPP) & 101.5 billion $\$(83$ th $)$ & 2.737 trillion $\$(11 \mathrm{th})$ \\
\hline GDP (OER) for 2015 & 37.76 billion $\$$ & 2.488 trillion $\$$ \\
\hline GDP per capita (PPP) & $14.200 \$(116$ th $)$ & $42.400 \$(38 \mathrm{th})$ \\
\hline GDP - real growth rate & $2.5 \%(114$ th $)$ & $1.3 \%(167 \mathrm{th})$ \\
\hline Gross national saving & $14 \%$ of GDP $(125 \mathrm{th})$ & $21.9 \%(67$ th $)$ \\
\hline Unemployment rate & $18.9 \%$ (168 th) & $9.7 \%(113$ th $)$ \\
\hline Taxes and other revenues & $42.9 \%$ of GDP (28 th) & $51.8 \%$ of GDP $(12$ th $)$ \\
\hline Budget surplus or deficit & $-2.3 \%$ of GDP (74 th) & $-3.2 \%$ of GDP (112 th) \\
\hline Public debit & $78.5 \%$ of GDP (31 th) & $96.5 \%$ of GDP $(17$ th $)$ \\
\hline Inflation rate & $1.1 \%(28$ th $)$ & $0.3 \%$ (44 th) \\
\hline Exports & 12.85 billion $\$(75$ th $)$ & 505.4 billion $\$(7$ th $)$ \\
\hline Imports & 17.37 billion $\$(79$ th $)$ & 525.4 billion ( 7 th) \\
\hline Debt - external & 31.64 billion $\$(77$ th $)$ & 5.36 trillion $\$(4$ th $)$ \\
\hline
\end{tabular}

Source for Serbia: The World Factbook, Central Intelligence

Agency https://www.cia.gov/library/publications/the-world-factbook/geos/ri.html

Source for France: The World Factbook, Central Intelligence

Agency https://www.cia.gov/library/publications/the-world-factbook/geos/fr.html

Mutual trade relations between the two countries are assessed as traditional, with a tendency of continuous improvement. France is among the ten most important foreign trade partners of Serbia. Of course, by comparing the macroeconomic indicators, we are confronted by a big difference in terms of area, population and development levels of the two countries. According to the data from Table 1, the value of French GDP (\$2.737 trillion) is significantly higher than that of Serbia ( $\$ 101.5$ billion), whereas the GDP per capita is three times bigger. Other macroeconomic indicators point to the fact that France is one of the strongest economies of the world, while Serbia is below the European average. Regarding exports, France is at the 7 th place in the world with $\$ 505.4$ billion, while Serbia is at the 75 th place with $\$ 12.85$ billion. Public debt, inflation and unemployment rates are much higher in Serbia than in France.

Table 2: Mutual trade relations between Serbia and France

\begin{tabular}{|c|c|c|c|c|c|c|c|c|c|c|}
\hline Years & Export & Index & $\begin{array}{l}\text { Share } \\
\text { of total } \\
\text { export }\end{array}$ & Import & Index & $\begin{array}{l}\text { Share } \\
\text { of total } \\
\text { import }\end{array}$ & Total & Index & Saldo & $\begin{array}{l}\text { Coverage } \\
\text { rate of } \\
\text { imports by } \\
\text { the exports }\end{array}$ \\
\hline 2011 & 221.8 & 106.3 & $2.6 \%$ & 385.0 & 107.1 & $2.7 \%$ & 606.8 & $106.8 \%$ & -163.2 & $57.6 \%$ \\
\hline 2012 & 220.0 & 99.2 & $2.5 \%$ & 400.4 & 104.0 & $2.7 \%$ & 620.4 & $102.2 \%$ & -180.4 & $54.9 \%$ \\
\hline 2013 & 264.3 & 120.1 & $2.4 \%$ & 453.6 & 113.3 & $2.9 \%$ & 717.9 & $115.7 \%$ & -189.3 & $58.3 \%$ \\
\hline 2014 & 313.6 & 118.7 & $2.8 \%$ & 431.6 & 95.1 & $2.8 \%$ & 745.2 & $103.8 \%$ & -118 & $72.6 \%$ \\
\hline 2015 & 368.5 & 117.5 & $3.1 \%$ & 480.5 & 111.3 & $2.9 \%$ & 849 & $113.9 \%$ & -112 & $76.7 \%$ \\
\hline $2016 / 6^{*}$ & 182.4 & 98.7 & $2.8 \%$ & 278.7 & 111.8 & $3.3 \%$ & 461.1 & & -96.3 & $65.4 \%$ \\
\hline
\end{tabular}

* Data for 2016 refer only to the first six months

Source: Serbian Chamber of Commerce (PKS) http://www.pks.rs/Predstavnistva.aspx?id $=4 \& \mathrm{t}=4 \& \mathrm{jid}=1$ 
The dominant form of economic cooperation is the exchange of goods. According to the data from Table 2, the trade volume has increased significantly to almost 850 million euros in 2015, which is 14\% more than in 2014 and $80 \%$ more than in 2010. Until 2013, France ranged at the thirteenth position on Serbia's export partner list, and since 2014, it moved to tenth position. Current imports of Serbia amount to 480.5 million euros, which is $11.3 \%$ more than in 2014.

Figure 1: The main products imports/exports products from/to France

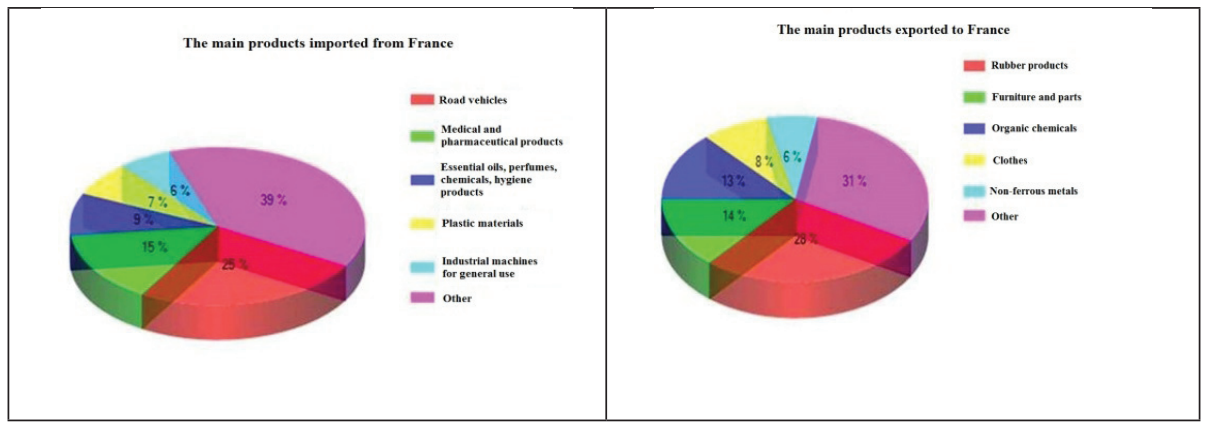

Source: Serbian Chamber of Commerce (PKS) http://www.pks.rs/Predstavnistva.aspx?id $=4 \& \mathrm{t}=4 \& \mathrm{jid}=1$

Some of the main products imported from France include road vehicles, medical and pharmaceutical products, essential oils, perfumes, chemicals, hygiene products, plastic materials, industrial machines for general use, electronic devices, etc. (see Figure 1). Serbia's export towards the French market has tripled and amounted to 370 million euros, which is $17.5 \%$ more than in 2014 . The coverage rate of imports by the exports increased from $50 \%$ to $76.7 \%$. Thanks to the increasing Serbian exports, the deficit which has been burdening Serbia for years (see Table 2) is now reduced to 112 million euros. The total export of Serbian products to France can be divided into five major groups (see Figure 1):

- Exports of vegetables and fruit (mainly red fruits);

- Exports of clothing;

- Semi-finished iron and steel exports;

- Export of non-ferrous metals;

- Exports of rubber products.

Though, economic relations are not yet at the level where they could be, compared to foreign trade with other countries (Vukovic \& Djokovic, 2015, p. 163). For example, in Romania, ${ }^{3}$ there are around 4000 companies operating in all fields of industry. In Romania, France is at the third place as a buyer and at the fourth place as a supplier, and bilateral exchange was increased by $9.3 \%$ compared to 2015 , reaching 7.4 billion euros. In order to improve the results, Serbia should engage in promoting its economy towards the French investors. The greatest opportunity for Serbian companies lies in interconnecting and engaging of our food suppliers, metal processing, chemical and pharmaceutical industry. The potential exists primarily in marketing of organic agricultural products and foodstuff. This market is developing intensely in France and is growing at a rate of $19 \%$ per year, thus presenting a great opportunity 
for certified producers. An agreement was signed in the field of agriculture in March 2012, which aims at expanding the cooperation in the agro-industrial sector. Seventy of our companies are already exporting frozen fruit to France, and raspberry exports were increased by a third compared to 2014, amounting to 50.6 million Euros, which is $14 \%$ of total exports, thus making Serbia the primary exporter of raspberries to France (Čadež, 2016, p. 17).

The language barrier can be identified as a key problem in the foreign trade management. Kovacevic (2012) states that the challenges and the temptation to the local companies' managers to communicate with the foreign market are increasing (p. 416). Sales managers are at a disadvantage if they do not speak the language of the local client or do not know its culture (Lekovic, 2006, p. 200). Language is a key tool in business communication as "there will be no business activities if there is a lack of communication" (Rakita, 2006, p. 602). Good business communication can increase profits, just as a bad one can reduce them (Miletic \& Djurovic, 2015, p. 51). Trust is the basis of every business relationship and communication with the customer in the native language thereof is an important factor in the building of that trust. "Knowledge of foreign languages can be seen as a means of creating and improving interpersonal relationships, as well as a means of understanding the dynamics of the associated culture" (Rakita, 2006, p. 608). For this reason, three roundtables were organized last year titled Jezičke strategije ${ }^{4}$, which aimed at encouraging the dialogue about how important the learning of French language is to the companies in Serbia, especially to those which plan to operate in the francophone market. Just as to the survey conducted at such companies that do business or plan to do business with the French-speaking market, 93\% of participants agreed that Serbia lacks professional staff that speaks French. When asked what is the main obstacle for Serbian companies when presenting themselves to the French market?, the most common responses included language barriers, lack of French language knowledge and ignorance of the culture of the French market.

Knowledge of the French language can greatly facilitate business in the French market. Although it may seem extremely difficult to master the French language at first glance, there are modern methods ${ }^{5}$ of language learning adapted for the company's particular needs, whereby the learners can in record time master the essential language skills needed for the purpose of business communication (Zivkovic, 2013, p. 213, 222). France is the country with a rich tradition and is a former colonial power which holds high regards towards its language. To succeed in business with French businessmen, one must be familiar with French culture, their habits, and especially their language. Although most business people in France speak English language, everyone who puts the effort into learning at least some basic French phrases will earn the respect of the French partners (Jones, 2011). Within the European Union, the French language has the status of an official and business language. Being the official language of 25 countries, likewise the languages of many international organizations, French is one of the most influential languages in the world after English.

\section{Intercultural differences}

Understanding the differences is essential for the establishing of business communication with foreign partners. "It always starts with getting to know the basic dimensions and characteristics of the culture of your interlocutors" (Rakita, 2006, p. 602). Hence, conducting business with France is closely linked to the knowledge of French 
culture and language. On the other hand, the lack of social and cultural differences may cause serious difficulties in building business relationships (Zivkovic, 2016, p. 145). Between France and Serbia, there are many prominent social, cultural and economic differences. Serbia is a country with many political, economic and social problems, and is in the process of transition that has lasted for more than a quarter of a century, while France is an EU member and the eighth country in the world in regards to economy - a fact which is certainly reflected in the business.

In agreement with Hall's analysis, it is possible to conclude that the Serbs, just like the French, are polychrome in culture i.e they can do more things at the same time. Deadlines are flexible, the timetable is not respected strictly, with a preference more towards establishing good relations with people, they often change their plans, they pay great attention to tradition and so on (Loth, 2006, p. 40; Rakita, 2006, p. 596-598; Hall, 1984). The fact that there are many similarities between French and Serbs has been noticed by many businessmen - they are creative and know how to enjoy, but they also have similar flaws as they are grumpy and big loudmouths. There are stereotypes that the French tend to turn business negotiations into "a play" and to not focus enough on the essence. For both French and Serbs, it is preferable to start the negotiations at the table with good food and good wine (Coste, 2010, p. 153). Before commencing any negotiations on the subject of work, it is also advisable with the French to begin with a talk about peripheral matters, such as the actual sport events or tradition. While this may seem like a waste of time, it is a way to better acquaint with business partners and is the very basis for good relations in the future. In a word, they should become capable of reaching an agreement easily. Also, between 12AM and 2PM, one should not attempt to make an appointment because at that time the majority of French are likely to have a lunch break.

Pursuant to Hofstede, the national culture is defined by four dimensions, (on a scale of 0 to 100): power distance, masculine versus feminine, individualism against collectivisms and uncertainty avoidance (Stoner et al., 2000, p. 128). In Serbia, just as in France, the large imbalances in power, status and wealth are held in high regard (see Table 3). Organizations usually have a pyramidal hierarchy with multiple levels, whereby the director is usually very difficult to reach. When establishing initial contact with a French business partner, respecting formalities and the hierarchy is of great importance. It is necessary to be aware that many business arrangements are being conducted at several levels. French companies have a vertical chain of command, so it is recommended that any task of strategic importance is presented directly to the Director General (PDG) first, and later continued with the managers at lower hierarchic positions. It is advisable to schedule meetings several weeks in advance (Rakita, 2006, pp. 600-601).

Table 3: Defining the cultural differences between France and Serbia after Hofstede

\begin{tabular}{|l|l||l||}
\hline \multicolumn{1}{|c|}{ France } & \multicolumn{1}{|c|}{ Serbia } \\
\hline Power distance & $\begin{array}{l}\text { Average, but highest among Western } \\
\text { countries }(\mathrm{n}=68)\end{array}$ & Big $(\mathrm{n}=86)$ \\
\hline $\begin{array}{l}\text { Individualistic } \\
\text { Collectivistic }\end{array}$ & Individualistic $(\mathrm{n}=71)$ & Collectivistic $(\mathrm{n}=25)$ \\
\hline Masculine/feminine & More feminine $(\mathrm{n}=43)$ & More feminine $(\mathrm{n}=43)$ \\
\hline $\begin{array}{l}\text { Uncertainty } \\
\text { Avoidance }\end{array}$ & $\begin{array}{l}\text { Great tendency to avoid the } \\
\text { uncertainty }(\mathrm{n}=86)\end{array}$ & $\begin{array}{l}\text { Extremely high tendency to avoid } \\
\text { the uncertainty }(\mathrm{n}=92)\end{array}$ \\
\hline
\end{tabular}

Source: Bollinger \& Hofstede (1987); Kohun \& Burčik (2012) 
Being a far cry from Serbia, which is mainly collectivist country with a greater need for social life, France is an individualistic country that upholds freedom of thought, which often manifests itself in the business culture, with a strong emphasis on respect for rules and regulations. Both countries have a fairly feminist culture that is characterized by orientation of care towards others, solidarity and quality of life. Doing service is considered to be more appropriate than achieving personal ambitions. France and Serbia are also cultures with strong uncertainty avoidance. It is in the very nature of French companies not to engage in risky business ventures, especially when it comes to SME. However, they do attempt to overcome the uncertainty by creating various legal, technological and religious institutions.

\section{Conclusion}

France and Serbia have had traditionally friendly relations for almost two centuries, with a lot of similarities in culture. Even though, they generally have different positions in the world and in international economic relations, their mutual co-operation seems to be on the right track. Nevertheless, while economic exchanges are moving upwards, when it comes to the existing potential for cooperation, the scope and structure of foreign trade is not at a desired level. It is referentially sufficient to compare the foreign trade exchange between Serbia and Germany or Italy or, on the contrary, the volume of French investments in Romania.

The reasons for this should predominantly be looked for in the negative image of the business milieu in Serbia. Unfortunately, on the international scene, Serbia has so far mainly been known for its political issues, while its economic potential is very little known. This is one reason why French businessmen have scarce knowledge about the economic potential of Serbia. In Paris in September 2016, a meeting was organized in order to provide information and contacts to Serbia. During this event, French companies were presented with advantages of the Serbian economy. It is necessary to put additional efforts into the continuous promotion of Serbia as a desirable destination for investors.

The new global market conditions and business environment of our country require employees to acquire the new skills and knowledge conductive to adapt to the global business conditions (Bejatović \& Bejatović, 2014, p. 136). By establishing the strategies for French language learning and familiarizing with the French culture within the company, it would be possible to overcome the language barrier in the process of establishing good bilateral economic relations. Our belief is that such actions would partially solve the problems of economic relations between Serbia and France. More than that, learning business French should be supported at all levels of the educational system. Additionally, teaching French language should be adapted to the current economic situation in Serbia.

\section{References}

Bejatović, M. \& Bejatović, G. (2014). Prilagođavanje razvojnih strategija domaćih preduzeća uslovima globalnog poslovanja. Ekonomika, 60(4), 131-138.

Bollinger, D. \& Hofstede, G. (1987). Les differences culturelles dans le management Comment chaque pays gere-t-til ses hommes? Paris: Edition d'organisation. 
Central Intelligence Agency, The World Factbook, from: https://www.cia.gov/library/ publications/the-world-factbook/ (Accessed 14 March, 2017).

Coste, P. (2010). S'implanter en Serbie. Belgrad: Ubifrance.

Čadež, M. (2016). Imamo adute za francuske investitore in Francusko-srpska ekonomska saradnja. Beograd AIM, 16-18.

Hall, E. T. (1984) La danse de la vie - temps culturel, temps vécu. Paris : Seuil.

Kohun, G. F. Burčuk, V. \& Skovira, R. J. (2012) Research into Hofstede's thesis in Managment, Knowlage and Learning, from: http://issbs.si/press/ISBN/978-961 6813-10-5/papers/ML12_213.pdf (Accessed 15 March, 2017).

Konstadinović, I. \& Petrović-Ranđelović M. (2015). Uloga i značaj slobodnih zona u privrednom razvoju: iskustvo Republike Srbije i Evropske unije Ekonomika, 61(4), 97-108.

Jones, M. (2011). Doing Business in France: 8 Cultural Cues That Make (or Break a Deal, from: http://www.ibtimes.com/doing-business-france-8-cultural-cuesmake-or-break-deal-368258 (Accessed 10 March, 2017).

Kovačević, R. (2012). Ekonomski odnosi Srbije sa inostranstvom. Beograd: CID Ekonomskog fakulteta u Beogradu.

Leković, B. (2006). Principi Menadžmenta. Subotica: Ekonomski fakultet.

Loth, D. (2006). Le management interculturel. Paris: Harmattan.

Markon, A. (2016). Ima prostora da mnogo više sarađujemo in Francusko-srpska ekonomska saradnja. Beograd: AIM, 8-10.

Miletić, S. \& Đurović, Đ. (2015). Unapređenje interesa preduzeća kroz process poslovnog komuniciranja. Ekonomika, 61(1), 43-53.

PKS - Privredna komore Srbije, Bilateralna saradnja, from: http://www.pks.rs/ Predstavnistva.aspx $\mathrm{id}=4 \& \mathrm{t}=4 \& \mathrm{jid}=1$ (Accessed 03 April, 2017).

Politika, (02 septembar 2013), from: http:/www.politika.rs/scc/clanak/268848/ Povratak-Francuske-na-Balkan (Accessed 03 April, 2017).

Sretenović, S. (2009). Francusko-srpski odnosi u XIX i XX veku. Biblid LXI(4), 536-558.

Rakita, B. (2006). Međunarodni biznis i menadžment. Beograd: CID Ekonomskog fakulteta u Beogradu.

Stoner, Dž. A., Friman, R. E. \& Gilbert, D. R. (2002). Menadžment. Beograd: Zenid.

Vuković, A., Đoković, G. \& Pavičević, A. (2015). Globalna kretanja u trgovini sa osvrtom na srbiju. Ekonomika, 61(4), 155-166.

Živković, D. (2013). Multilingvistički pristup spoljnotrgovinskoj razmeni kao faktor privrednog rasta Republike Srbije. Business economics, godina VII, 8(2), Sremska Kamenica, Educons, 211-227.

Živković, D. (2016). Le plurilinguisme et l'interculturalisme - les ressources cachées du commerce international. In Diversité culturelle et plurilinguisme (pp. 143151). Cluj-Napoca: Technical University. 


\section{Endnotes}

1. Interim Trade Agreement (ITA) was signed in 2010 and the Stabilization and Association Process (SAP) was signed in 2013, which defines the partnership between Serbia and the EU. For more information see the following link: http://www.ccfs.rs/sr/upoznajte-srbiju/republika-srbija/medunarodnisporazumi/ (14th April, 2017).

2. For more information see the following link: https://issuu.com/cordmagazines/ docs/francuska_srpska_ekonomska_saradnja (8th April, 2017).

3. The results of foreign trade between France and Romania and the French investments in this country, taken from the website of the French Government, see the following link: http://www.tresor.economie.gouv.fr/Pays/roumanie/ echanges-et-investissements (5th April, 2017).

4. During the month of Francophonie in Niš, Belgrade and Novi Sad, three roundtables on the topic "Economic Francophonie" were held. During these debates, participants were able to share their experiences in dealing with French-speaking market, as well as to draw attention to some of the problems they face, and were related to the lack of knowledge of French language and culture. For more information see the following link: http://www.ccfs.rs/sr/ single-news/n/okrugli-sto-o-privrednoj-frankofoniji/ (10th April, 2017).

5. French for specific purposes is the method that is being developed in cooperation with the Chamber of Commerce of Paris and is mainly aimed at business people who plan to do business on the francophone market. The main characteristic of this is to analyze the communication needs of different businesses, on the basis of which a method is created which can educate students only for the purposes for which they are learning the language in the first place. It is mainly aimed at business people who are planning business ventures on the francophone market. For more information see the following link: http://www. centredelanguefrancaise.paris/numerifos/ (23th March, 2017). 